\section{From an Ethics of \\ Estrangement to an Anthropology in Life}

\section{CAROLINE GATT (1) \\ DIEGO GALAFASSI (D) \\ GEY PIN ANG}

*Author affiliations can be found in the back matter of this article
SPECIAL

COLLECTION:

SPECIAL ISSUE OF ILLUMINATED VIDEOS VIDEO ARTICLE

\section{(3)H}

Open Library of Humanities

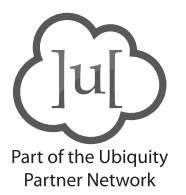

CORRESPONDING AUTHOR:

\section{Caroline Gatt}

University of Aberdeen, GB

C.gatt@abdn.ac.uk

\section{KEYWORDS:}

Anthropology; Laboratory Theatre; Listening; Difference and Alterity; Academic Orthopraxy; Collaboration

TO CITE THIS ARTICLE: Gatt, C, Galafassi, D and Ang, GP. 2021. From an Ethics of Estrangement to an Anthropology in Life. Journal of Embodied Research, 4(2): 6 (20:21). DOI: https://doi. org/10.16995/jer.69 
VIDEO ARTICLE

Available to view here: https://doi.org/10.16995/jer.69.

Available for download here: https://doi.org/10.16995/jer.69.s1.
Gatt et al.

Journal of Embodied

Research

DOI: $10.16995 /$ jer.69

\section{STILLS FROM THE VIDEO ARTICLE}
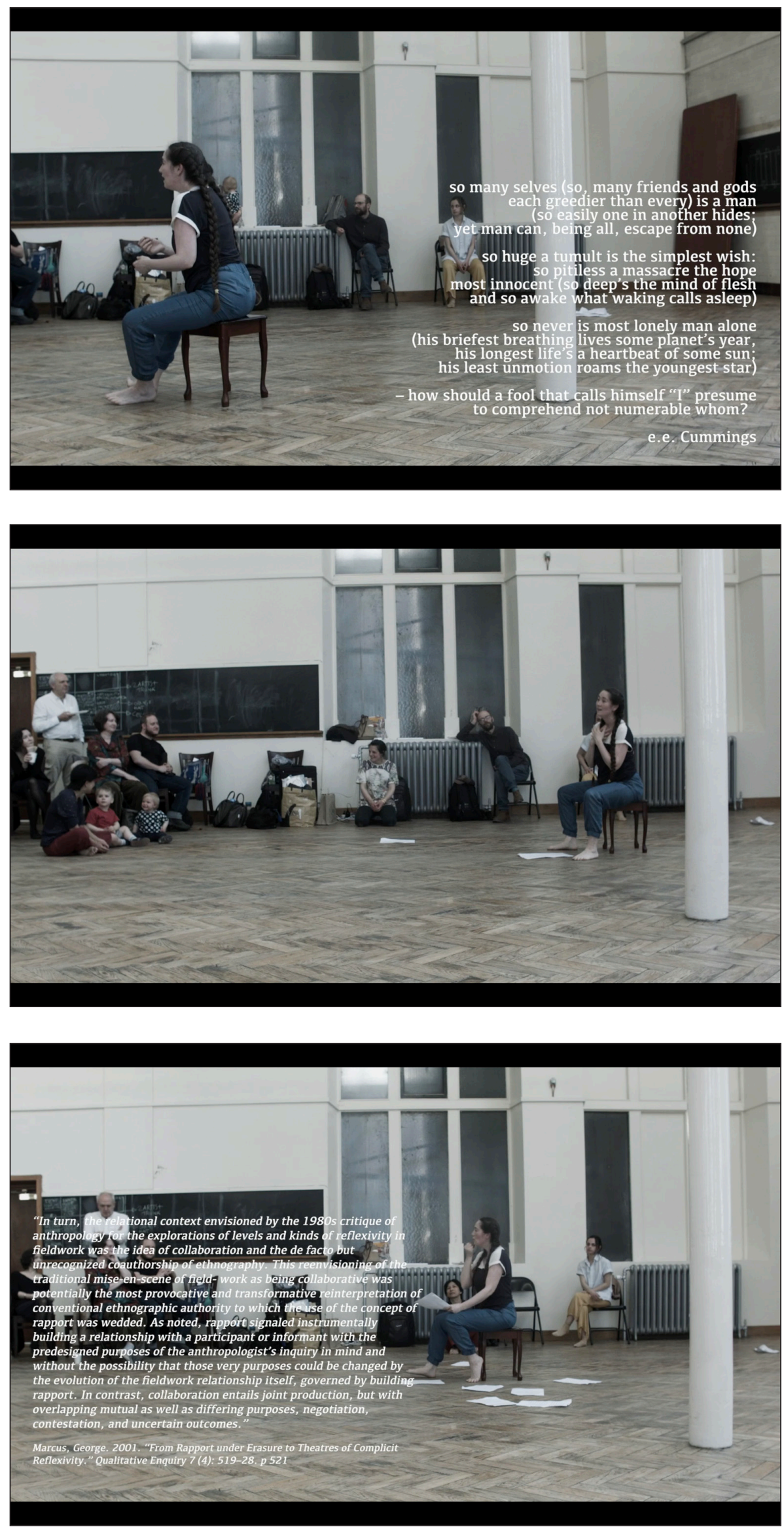


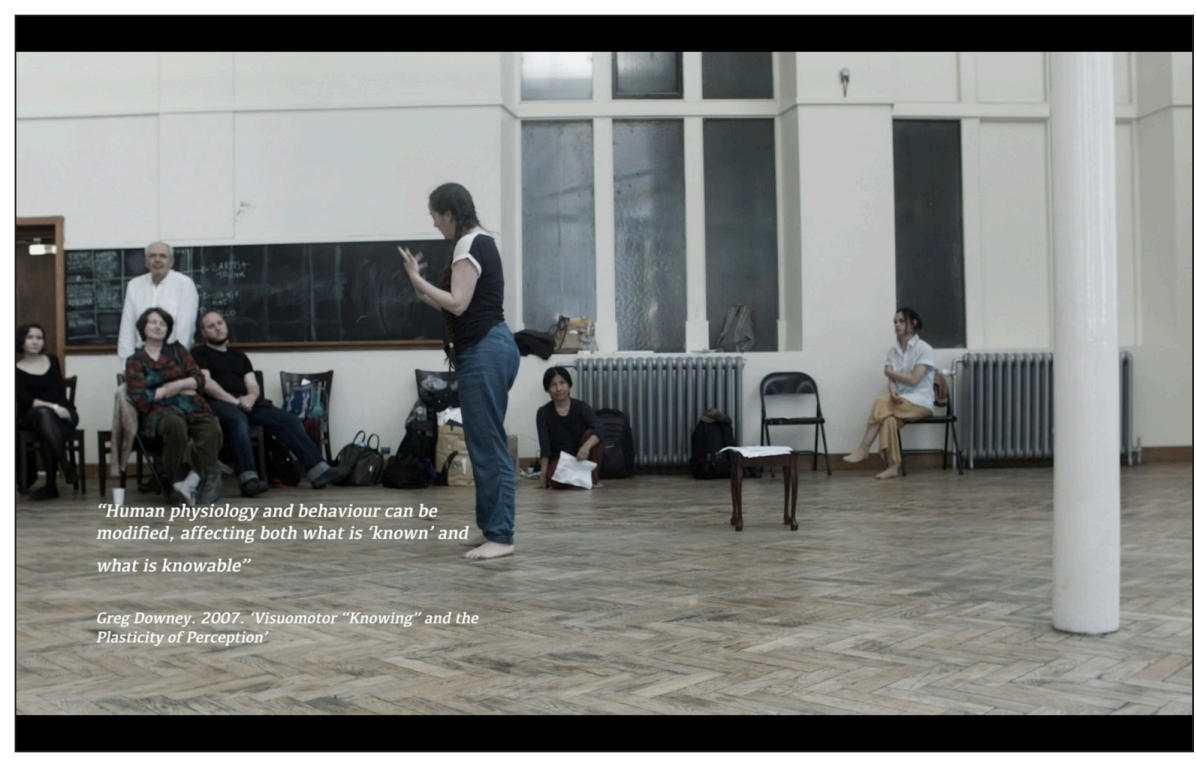

\section{VIDEO ARTICLE TRANSCRIPT}

[Note: This is a transcript of a video article. Individual elements from the transcript, such as metadata and reference lists, may appear more than once in the document, in order to be properly read and accessed by automated systems. The transcript can be used as a placeholder or reference when it is not possible to embed the actual video, which can be found by following the DOI.]

[00:10]

Attending to Journal of Embodied Research's provocation, this video essay was created from an uncut video. Liberated from the editing process, what was initially intended as a b-roll became main footage.

The session started as people arrived to the venue, while one of the cameras was being prepared.

Some of the text illuminations contain long quotes. we suggest pausing the video for reading as they only remain in frame for 5 seconds.

\section{[Caroline Gatt:]}

what waking calls asleep

and so awake what waking calls asleep

so never is most lonely man alone

so many selves (so, many friends and gods each greedier than every) is a man (so easily one in another hides; yet man can, being all, escape from none)

so huge a tumult is the simplest wish: so pitiless a massacre the hope most innocent (so deep's the mind of flesh and so awake what waking calls asleep)

so never is most lonely man alone (his briefest breathing lives some planet's year, his longest life's a heartbeat of some sun; his least unmotion roams the youngest star) -how should a fool that calls himself "I" presume to comprehend not numerable whom? 
e.e. Cummings

his briefest breathing lasts some planet's year, his longest life's a heartbeat of some sun; his least unmotion roams the youngest star so how could the fool that calls him 'I' presume to comprehend not numerable whom?

\section{From an ethics of estrangement to an anthropology in life}

\section{Caroline Gatt, Diego Galafassi, with Gey Pin Ang}

\section{[01:31]}

Ha! but I feel I am I

We present here an experiment in allowing the way of knowing/being of laboratory theatre to affect anthropological orthopraxy, in this case a conference presentation.

and when I got to work in 2013, thinking, "What do I want to explore in this KFI project?" I presented this poem by E. E. Cummings.

"KFI - Knowing From the Inside - seeks to reconfigure the relation between practices of inquiry in the human sciences and the forms of knowledge to which they give rise. Its fundamental premise is that knowledge is not created through an encounter between minds furnished with concepts and theories, and a material world already populated with objects, but grows from the crucible of our practical and observational engagement with the world around us. Knowledge, we contend, comes from thinking with, from and through beings and things, not just about them. Our overall aim is to show how research underpinned by this premise could make a difference to the sustainability of environmental relations and to the well-being that depends on it."

https://www.abdn.ac.uk/research/kfi/ (accessed 10th October 2020)

And the following question: What are the refractions of the very personal within large scale policy artefacts, and what is the extensive within persons? How are environments of learning carried within persons?"

"What are the refractions of the very personal within large scale artefacts such as environmental policy and what are the refractions of the extensive within the person, how are environments of learning carried in persons?"

Caroline Gatt, Sub Project 3 Environments of Policy and Practice, Knowing from the Inside.

https://www.abdn.ac.uk/research/kfi/people/aberden-project-members/c-gatt/?action=subpage (accessed 10th October 2020)

So, the work I want to share and discuss with you today has been coming a long time, from 2013, but way back from 2004, when I wanted to write a PhD, to come to Aberdeen to work with Tim, about the epistemology inherent in laboratory theatre. But my lecturers told me, "Sorry, this is not an anthropology project. Why don't you do your PhD with Friends of the Earth? You're working with this organization; do your Phd on that."

"If knowing is ongoing and practical, a form and method - a crafting - has to be initiated which captures the process adequately. This approach is an attempt to achieve consistency across the stages of the knowing of others. It is no good being interested in experience as an analytical concept, for example, and only writing about verbal reports on the topic. Experience should be integrated in theoretical perspective (e.g. phenomenology), a fieldwork method (e.g. participant learning..., or participant perception rather than observation) and a form (e.g. writing which evokes the textures of experience)."

(page 2) Mark Harris. 2007. "Ways of knowing”, in Harris (Ed) Ways of Knowing: Anthropological Approaches to Crafting Experience and Knowledge. New York; Oxford: Berghahn Books. P 1-26. 
So, being young and afraid of the future, I, I complied. And I was working with Friends of the Earth International at the time, as a local project coordinator in Malta.

Friends of the Earth International

https://www.foei.org

Friends of the Earth International is a federation of grassroots environmentalist organizations. Currently... Sorry!

"To achieve the aims of disciplinary decolonization implied in anthropologies otherwise, we will argue that the craft of anthropology needs to be revisited, not only the content of conceptual work. This disciplinary complex encompasses the daily practices of anthropology in universities, including the audiences to whom anthropologists are account- able. Taking Holbraad's (2012) provocation seriously, why not take recursive anthropology a step further? We could take cues from what we learn in fieldwork to renew our ways of enacting, as well as our ways of thinking, anthropologically, which are anyway intrinsically enmeshed in one another."

(page 182) Ang, Gey Pin and Gatt, Caroline. 2018. "Crafting Anthropology Otherwise: Alterity, Affinity and Performance", in Chua and Mathur (Eds.), Who Are We? Reimaginging Alterity and Affinity in Anthropology. New York; Oxford: Berghahn. P 179-206.

Currently, there are seventy-six member groups. Sorry, Jan. Seventy-six member groups all around the world. And I thought at the time, when I wrote this PhD proposal, that it was a complete detour from theatre and song. But now I realize that without that experience of working with Friends of the Earth, I wouldn't have come to value or realize what the specific and political implications laboratory theatre, in its way of working, carries.

What is a "good" anthropological presentation?

What is the unquestioned orthopraxy of academic anthropology?

What forms of movement, expression, practices of presentation, which relations are allowed and which are not?

Which onto/epistemologies are considered properly anthropological and which need to be 'translated' into more 'conceptual' or 'intellectual' packages to be considered anthropological?

So what I want to do now in the next ten minutes, is share with you a little bit of a reflection about the...A LITTLE BIT OF A REFLECTION ABOUT THE GREAT POLITICAL VALUE IN LABORATORY THEATRE. Seriously, though, seriously, though, and I also have another year left in KFI, so your thinking is welcome and will help me move on.

So, just a little bit of a background about myself. I started my theatre training at the same time as my undergraduate studies in anthropology. Ahhh.

"[Confessional autobiography] in the context of anthropological fieldwork, ...could be an attempt to analyse the actual research process in place of an idealised, scientised presentation."

(page 5) Okely, Judith. 1992. "Anthropology and Autobiography: Participatory experience and embodied knowledge", in Callaway and Okely (Eds), Anthropology and Autobiography. London; New York: Routledge. Pp 1-28.

But although I carried on working, mainly, in anthropology - my studies were in anthropology - I carried on doing workshops with different theatre people, makers, working with some groups, and I realized that theatre wasn't going to leave me alone. It kept following me around. And the thing was that the people who I was working with turned out to be either people who had worked with Jerzy Grotowski, who is a twentieth-century theatre maker, or with people who had worked with people who had worked with Jerzy Grotowski. So, basically, I found myself in an environment which can be called the legacy of Grotowski.

Magnat, Virginie. 2013. Grotowski, Women and Contemporary Performance: Meetings with Remarkable Women. New York; London: Routledge. 
Salata, Kris. 2012. "The poetics of the encounter: Grotowski's living legacy” In: Jerzy Grotowski. L'eredità vivente [online]. Torino: Accademia University Press.

And the thing that excites me most about this world is that it takes, it has a very rigorous curiosity about what encounter is, what it means to meet somebody and listen.

Ah.

[Child:]

It's Caroline

[Caroline Gatt:]

It is!

"Grotowski is quintessentially anti-systemic. Of course, though, by virtue of a paradox, his entire practice was marked by a programmatically methodical mode of working - the Wrockaw Laboratory Theatre was indeed named the Institute for Studies of the Method of Acting (later Actor's Institute) - while its motto was always discipline. At the same time, though, Grotowski was a great believer in spontaneity... If Grotowski's approach is to be considered indeed antisystemic, then it is to be so for the reason that he valued more highly than any system, with its regularity and schematism, the actual experiencing of life in all its unpredictable spontaneity and unfathomable wealth - as élan vital."

Leszek Kolankiewicz "GROTOWSKI'S ARS MAGNA" https://grotowski.net/en/encyclopedia/grotowskijerzy (Accessed 10th October 2020)

but also, the way that Grotowski writes about his work is that it is anti-method. Where's Jan? Anti-method. And anti-recipe. Because every time you meet somebody else, every time you meet somebody else, it's always going to be a new encounter. And you can't take for granted that any of your previous experiences are going to count. So it's a constant rediscovery.

It's okay, Kate I really don't mind. I wish Mariuccia were here.

[Kate Stewart:]

Do you want me to leave them, or do you want me to...

[Caroline Gatt:]

Yeah...As long as they're not...Can you hear me? Okay. I want you to hear me.

[07:01]

The relations anthropologists, indeed the relations anyone engages in throughout their life participate in generating what is considered 'knowledge', including the relations unfolding during conference presentations. Revisiting how we know needs to unpack all assumptions, including the boundaries current academic practices draw between work and family.

So, basically, the training of laboratory theatre focuses on how encounter is about being open to encountering difference, because every time, it's going to be different. And difference is clearly central within anthropology. In the history of, in the history of the discipline, difference has been a key concept that organizes the debates. And it still is a very important debate, how to deal with alterity, with otherness. And my motivation for working with Gey Pin, who I will introduce in just a minute, has a lot to do with this disciplinary history. Especially since the sort of difference I've learned to encounter working with Gey Pin is a difference within oneself as well as difference which might be not within self, still confusing. And so the focus of the collaboration between Gey Pin and myself has been how to allow the craft of anthropology and the craft of theatre inquiry to mutually nourish each other.

So, I'll briefly introduce Gey Pin, and Gey Pin worked with the [inaudible]... Gey Pin! ... hi, Ben. 
Gey Pin Ang has a Practice-as-Research Ph.D. from the University of Kent. A performer and pedagogue, she is a recipient of the Theatre Artist Award, Singapore. Ang graduated from the University of Hawaii with a BA in Theatre in 1992, and performed lead roles within the Project The Bridge: Developing Theatre Arts, of the Workcenter of Jerzy Grotowski and Thomas Richards, in Italy for more than 9 years. Since 2006, she has taught internationally via Sourcing Within Worksessions (sourcingwithin.org/) and collaborates with intercultural and interdisciplinary artists. Ang's current research explores the notion of 'care of the self' and the discoveries of the performer's potentiality via one's physical and vocal embodiment in a performative work.

Gey Pin worked with the Jerzy Grotowski and Thomas Richards Workcenter in Poland, uh, Pontedera, sorry, for over nine years in lead roles within the group. And then, in 2006, she set up Sourcing Within, having left the Grotowski and Thomas Richards Workcenter, she set up Sourcing Within, which is a platform that brings together multidisciplinary artists that she collaborates with and leads workshops.

https://sourcingwithin.org

And in 2013, I began participating in her workshops..

After a couple of these work sessions, I asked Gey Pin if she wanted to collaborate with me, and she said, "Alright, let's see. Let's give it a try."

Ang, Gey Pin and Gatt, Caroline. 2018. 'Collaboration and Emergence: The Paradox of Presence and Surrender', in Gatt (Ed) 'Anthropological Collaboration in the Making', Collaborative Anthropologies Vol 10 No 1-2: 66-93

Gatt, Caroline. 2015. 'The Anthropologist as Member of the Ensemble: Anthropological Experiments with Theatre Makers'. In: Alex, Flynn and Jonas, Tinius (Eds) Theatre as Change: The Transformative Potential of Performance, Palgrave. pp. 334-357.

And the focus would be how we would work together, which, in anthropology, is normally found within that, sort of, zone which is called 'fieldwork.' So now, I'd just like to talk a tiny bit about this thing of fieldwork. And we could consider, like one key element that is considered the mainstream aspect of fieldwork is an ethnographic attentiveness, whatever that is. And we could say, that this attentiveness, or this ethnographic attentiveness, is a process by which we come to be aware of our own assumptions about how the world is, what life is, how it's come to be that way, and how it could be. Now, historically, anthropologists would engage in this practice of making one's own assumptions known or visible by doing fieldwork in exotic places, somewhere very unfamiliar, right? Contrast was meant to bring out what those assumptions were. However, it took like quite a tempestuous debate, what we refer to as the crisis of representation, to realize that even with quite rigorous preparation, going on fieldwork didn't mean that you were automatically going to become aware of your associations simply by encountering difference.

"Anthropology out-contextualizes indigenous (Hawaiian or European) contextualizing efforts." P 160

Strathern, M. 1990 'Artefacts of History', in Culture and History in the Pacific, Siikala, J. (ed), The Finnish Anthropological Society

In fact, the anthropologist Marilyn Strathern argues that what could happen, what tended to happen, was that anthropological accounts explained away the explanations of the people who we were trying to listen to, basically. So, Viveiros de Castro, another anthropologist, has argued that, because of the depth with which these assumptions, sort of, lodge themselves in our listening to each other, we need to take seriously these accounts that we meet in fieldwork.

Viveiros de Castro, Eduardo, Martin Holbraad, and Morten Axel Pedersen. 2014. 'The Politics of Ontology: Anthropological Positions', Cultural Anthropology Online, 13 January. Retrieved from http://www.culanth.org/fieldsights/462-the-politics-of-ontology-anthropological-positions 
And what I find most interesting about his work and his arguments is that there is such a thing as epistemological colonization and domination. And that means that what is required is that we watch out and learn how we listen.

"The Vast and vastly diversified field of such experiences I designate as the anti-imperial South. It is an epistemological, nongeographical South, composed of many epistemological souths having in common the fact that they are all knowledges born in struggles against capitalism, colonialism and patriarchy." P1.

Boaventura De Sousa, Santos. 2018. The End of the Cognitive Empire: The Coming of Age of the Epistemologies of the South. Durham and London: Duke University Press

Back to Friends of the Earth. Working with Friends of the Earth, I found that this attitude of taking seriously was very present amongst the activists. They really wanted to listen to the differences between seventy-six groups.

Gatt, Caroline (2018a) An Ethnography of Global Environmentalism: Becoming Friends of the Earth. London; New York: Routledge.

They really wanted to make sure that the different ways of understanding nature and the relationship of people within that nature from the seventy-six groups had equitable space within the federation. The fact that they emphasized the grassroots aspect of their work led them to really valuing difference. So much so that in 2004, they embarked on this massive project called "Strategic Vision and Planning Process." And even if it has this horrible corporate name, it really had a genuine hope that the different groups would have space to, not only have different ideas, but different ways of communicating those ideas and different ideas of politics. So, it was really, it took more than ten years, and it's an ongoing thing. But it was a commitment from the whole federation.

But, in that federation, in that whole process, there was no attention given to how people learn to listen. So the activists found themselves a little bit at a loss. They really wanted to listen, but the fact that you needed to learn to listen was sort of, nobody offered them tools. And this is where my experience in theatre started calling for attention. Because the training in laboratory theatre is very much-and there are some wonderful people here who are practitioners, if I want to have a wider discussion, they can help me-so the very training of laboratory theatre is on how to pay attention, how to listen. And not only how to listen to words. How to listen in the broadest sense.

Jadi Carboni

www.jadicarboni.com

Adriana Josipovic at Kontejner

https://www.kontejner.org/o-nama/kontejner

Valeria Lembo

https://edinburgh.academia.edu/valerialembo

Ellie Nixon

https://www.bathspa.ac.uk/our-people/ellie-nixon

Ben Spatz at Urban Research Theater

https://urbanresearchtheater.com

Christopher Williams

http://www.christopherisnow.com

Now, that theatre can offer something to anthropology is not new at all. In the 80s, there were very famous experiments between Victor Turner and Richard Schechner, and they went on to develop performance studies as an area, 
Schechner, Richard. 1981. Between Theatre and Anthropology. USA: University of Pennsylvania Press.

Turner, Victor and Turner, Edith. 1982. "Performing Ethnography". The Drama Review: TDR 26: 33-50.

which was very different to theatre, drama, which was focusing on texts, right. And their experiments was very much about enaction and experience.

But what happened was that, over the year these experiments petered out, and really and truly in mainstream anthropology, we haven't heard of these experiments since. Except for Cassis Kilian that I recently discovered.

Kilian, Cassis. 2021. Attention in Performance: Acting Lessons in Sensory Anthropology. Routledge.

So, there's very little left of these experiments. It's all been folded back into the writing of texts, basically. And I wanted to avoid repeating that interest in theatre just to, sort of, extract concepts to use in texts.

"In turn, the relational context envisioned by the 1980s critique of anthropology for the explorations of levels and kinds of reflexivity in fieldwork was the idea of collaboration and the de facto but unrecognized coauthorship of ethnography. This reenvisioning of the traditional mise-en-scène of fieldwork as being collaborative was potentially the most provocative and transformative reinterpretation of conventional ethnographic authority to which the use of the concept of rapport was wedded. As noted, rapport signalled instrumentally building a relationship with a participant or informant with the predesigned purposes of the anthropologist's inquiry in mind and without the possibility that those very purposes could be changed by the evolution of the fieldwork relationship itself, governed by building rapport. In contrast, collaboration entails joint production, but with overlapping mutual as well as differing purposes, negotiation, contestation, and uncertain outcomes."

Marcus, George. 2001. "From Rapport under Erasure to Theaters of Complicit Reflexivity." Qualitative Inquiry 7 (4): 519-28. p 521

And so, what it ended up doing to me was that I attempted to allow the way of knowing of theatre to influence the whole range of activities that can be considered the craft of anthropology.

And that's where the work with Gey Pin became most valuable because, right from the beginning of our collaboration Gey Pin suggested, she suggested what if she would be the anthropologist and observe me in my theatre work. So that, when she's trying to understand how I'm working in the theatre work, she would be able to tell, have I, as an anthropologist, listened to what she's trying to share with me? And then we would be able to see through her feedback about my theatre work whether, as an anthropologist, I have listened to what was important to her and the practice.

The laboratory theatre practice that Ang and others in Grotowski's legacy develop is a form of enquiry that enables processual and ecological attention.

Gatt, Caroline. 2020. 'Breathing Beyond Embodiment: Exploring Emergence, Grieving and Song in Laboratory Theatre', Body and Society 26(2): 106-129.

And this has meant I've tried to incorporate studio time into my daily practice as far as is possible, carrying on the training, but also, we've written together, we've gone to conferences together. So, it's been an exchange of practices: writing, conferences, training... performance, next, no, Gey Pin? (Mela, what...)

What the collaboration with Ang enabled, where the way of knowing of laboratory theatre was invited to affect and recursively inform the craft of anthropology is two fold:

1. A possible path towards decolonising anthropology through collaborative processes attentive to onto/epistemology 
Ang, Gey Pin, and Gatt, Caroline. 2018. 'Crafting Anthropology Otherwise: Alterity and Performance', in Chua, L and Mathur, N. (Eds) Who are "We"? Reimagining Alterity and Affinity in Anthropology. Berghahn Books. p 179-206

Gatt, Caroline. 2018. Introduction to the special issue 'Knowing Collaboratively: Considering Onto/Epistemology in Collaboration' In: Gatt, Caroline (ed) Collaborative Anthropologies, vol. 10(1-2), pp. 1-19.

2. Attention to the worldly power of words and text that theatre focuses on, while logocentrism elides and which in part is the source of its ongoing hegemonic position. This opens up the possibility that the ideology of language as it is used in academic contexts needs to be entirely revised so that the way anthropologists record, analyse and use language takes into account the ethnocentric bias in the way language is currently taken for granted in the discipline.

Gatt, Caroline. In Prep. 'Introduction to the special issue 'Knowing by Singing', American Anthropologist under review.

And the place that I think I've ended up with at the moment is that learning to listen and learning to listen to difference (thank you Gey Pin) might mean that we have to change the whole way of living to be able to understand what we're hearing in that different... Let me start again.

The anthropologist Greg Downey does work with capoeiristas, and he observed, he noticed that in the training that capoeiristas do, they develop peripheral vision. And peripheral vision is specifically different to foveal vision, which is vision in focus. Now, reading develops foveal vision, whereas the work of capoeira, like of actors, needs to be attentive to the whole surrounding. And what Greg found is that it's the actual eye that becomes different. So, the training changes the physiology, and his...I have a quote of what his argument is, if I can find it... No, I'm not going to find it. I'm going to try and remember a quote.

"Human physiology and behaviour can be modified, affecting both what is 'known' and what is knowable"

Greg Downey. 2007. 'Visuomotor “Knowing” and the Plasticity of Perception’

He says that training actually changes the physiology of the capoeiristas, making what is, not only what is known different, but what is knowable. So, basically, different practices grow different bodies or living persons. And Mike Wesch, another anthropologist, puts it a bit differently:

"You can't think your way into a new way of living. You have to live your way into a new of thinking" - Mike Wesch

https://it.osu.edu/news/2019/03/25/anthropology-students-live-their-way-new-way-thinking

"We can't think our way into a new way of living. We have to live our way into a new way of thinking." And that might mean, that if we want to listen to difference, we might have to commit to different ways of life as academics.

"Hollering creaks, holloring creaks, hollering creaks to crack, hollering creaks to crack the gate keeper and the ivory tower's mirror, creaks can crack a mirror, a creak can crack a mirror, a creak can crack a mirror, keep out the creaks that turn into cracks we reaffirm our silences, you keep out the creaks that turn into cracks we reaffirm our silences, the creaks that turn to cracks that be to wild they need to be contained, the creaks that turn to cracks that be to wild they need to be contained, you either be that or disappear, why do they think so many black women in anthropology turn to the arts."

Gina Athena Ulysse

https://www.youtube.com/watch?v=xHhngXU8Zw4

And here is where we have a little bit of a, two problems. One problem is that in this anti-intellectual environment that we're living in, there is a lot of value to be given to writing, reading, analysis, and critique. So, it's not about valuing one way of knowing 
to the detriment of what is valuable about academic work; that's something that I want to emphasize. But also, my argument could turn against me. If we grow different bodies in order to be able to listen to difference, what happens if that closes off your ability to listen to other differences, right?

"[D]ifferent contexts of gaining familiarity can produce different understandings of what can be changed, and of where a person's energy and agency can be directed" so that "having agency towards a particular 'thing' may not even be considered a possibility, so that no attempts are made to direct attention towards it. This is what I call unprotected backs"...

p 197 \& P 193

Gatt, Caroline. 2018. An Ethnography of Global Environmentalism: Becoming Friends of the Earth. New York; London: Routledge.

So in the very argument that, by practicing, you can listen to difference, I've almost got myself into a corner. But, and this is where theatre comes, laboratory theatre has something to offer, because, as Christopher-where are you, Christopher-as Christopher said yesterday, the thing about improvisation is its commitment or its embracing of contingency, of the unknown.

If anthropologists are to take difference seriously they will need to open up to difference across the entire orthopraxy of the discipline, and revisit the craft of anthropology.

So, if the training is about being able to stay with the unknown, then rather than developing a body that is closed off to difference, it's actually one that's opening up to it.

[20:01]

From an ethics of estrangement to an anthropology in life

Caroline Gatt, Diego Galafassi, with Gey Pin Ang

This research was made possible thanks to funding from the European Research Council as part of the project Knowing from the Inside (Tim Ingold PI). We would like to thank Tim Ingold and other members of the KFI project for their support of this work. We would also like to thank Valeria Lembo and Adriana Josipovic for participating in the subsequent part of the presentation that is not shown in this illuminated video. Thanks to all members of the audience at the KFI gathering that with their attention contributed to generating the atmosphere of the presentation.

[20:11]

From an ethics of estrangement to an anthropology in life

Caroline Gatt, Diego Galafassi, with Gey Pin Ang

Abstract

Taking difference seriously is a key anthropological aim. Recent debates in anthropology surrounding the 'Ontological Turn' have brought to the forefront the need to recognise the extent of epistemological colonialism in anthropological accounts. Proponents of the Ontological Turn have suggested that to take difference seriously anthropologists should engage in recursive anthropology: enabling the concepts they encounter through fieldwork to reconfigure anthropological concepts. Where the OT stumbles is in failing to recognise that it is the entire orthopraxy of anthropology that needs to recursively be reconfigured when encountering difference. Herein we offer an experiment in allowing the way of knowing/being of laboratory theatre to affect anthropological orthopraxy, in this case a conference presentation. We argue that opening up the entire craft of anthropology to difference through collaborative processes offers a path towards decolonising anthropology and a method of enquiry that enables processual and ecological attention. The experiment we present aims towards developing a regenerative form of anthropology, attentive to histories of exclusionary relations of power of all sorts.

Keywords

Anthropology, Laboratory Theatre, Listening, Difference and Alterity, Academic Orthopraxy, Collaboration 
Author Bios

Caroline Gatt c.gatt@abdn.ac.uk University of Aberdeen

Caroline Gatt is Senior Research Fellow, Institute of Cultural Anthropology and European Ethnology, University of Graz and Co-Investigator on the project '(Musical) Improvisation and Ethics' funded by the Austrian Science Fund. She is an anthropologist and performer, author of 'Breathing Beyond Embodiment: Exploring Emergence, Grief and Song in Laboratory Theatre' (2020), and An Ethnography of Global Environmentalism: Becoming Friends of the Earth (2018) and editor of TITG Chapbooks (2022 with Joss Allen), and The Voices of the Pages (2017/2018).

Diego Galafassi diego.galafassi@lucsus.lu.se University of Lund

Diego Galafassi is a transdisciplinary artist from Brazil with a practice grounded at the interface of art, sciences and co-creative processes. He is a director, writer and producer of documentaries, experimental film, new media and participatory performance.

with

Gey Pin Ang geypinang@gmail.com Independent Artist

Ang Gey Pin is a theatre practitioner. Her Sourcing Within project promotes embodied research that unearths performer's organic impulses and reactions. Her works are featured in journals and books dedicated to intercultural theatre and anthropology. She holds a PhD in Drama by Practice-as-Research from the University of Kent.

Author Statement

The authors state that they have no competing interests.

\section{COMPETING INTERESTS}

The authors have no competing interests to declare.

\section{AUTHOR AFFILIATIONS}

Caroline Gatt (D) orcid.org/0000-0003-0509-4010

University of Aberdeen, GB

University of Graz, AT

Diego Galafassi (D) orcid.org/0000-0003-3572-9275

University of Lund, SE

\section{Gey Pin Ang}

Independent Artist, SG
Journal of Embodied

Research

DOI: $10.16995 /$ jer.69
TO CITE THIS ARTICLE: Gatt, C, Galafassi, D and Ang, GP. 2021. Caroline Gatt and Diego Galafassi with Gey Pin Ang. Journal of Embodied Research, 4(2): 6 (20:21). DOI: https://doi.org/10.16995/jer.69

Submitted: 23 October 2020 Accepted: 24 July 2021 Published: 11 October 2021

COPYRIGHT:

(C) 2021 The Author(s). This is an open-access article distributed under the terms of the Attribution-NonCommercialNoDerivatives 4.0 International License (CC BY-NC-ND 4.0), which permits unrestricted use, distribution, and reproduction in any medium, provided the original author and source are credited. See http:// creativecommons.org/licenses/ by-nc-nd/4.0/.

Journal of Embodied Research is a peer-reviewed open access journal published by Open Library of Humanities. 